\title{
Allied Health: engaging families in treatment
}

\author{
Zarah Matthews*', Heather Litchfield \\ From 2014 ANZAED Conference: Driven Bodies Driven Brains \\ Fremantle, Australia. 22-23 August 2014
}

Family support and involvement are fundamental in supporting a patient through their recovery journey. The Eating Disorders Unit at The Royal Melbourne Hospital offers a range of family support programs in different forums as a means to provide support and education to family members. We recognize that families come in a range of forms including parents, siblings, cousins, work colleagues and friends, so providing multiple services and forums give staff the opportunity to engage numerous families. Services include the provision of information packs on admission, family/carers meetings, family therapy, information nights, Building Hope family/carers workshop and discharge meetings.

Over the past year, the allied health team working as part of The Eating Disorders Unit has significantly expanded the family work component of the program. This has been met with great feedback and results, and has made for a much more positive therapeutic relationship between patients, their families and the treating team.

Published: 24 November 2014

doi:10.1186/2050-2974-2-S1-P3

Cite this article as: Matthews and Litchfield: Allied Health: engaging

families in treatment. Journal of Eating Disorders 2014 2(Suppl 1):P3.

\footnotetext{
* Correspondence: zarah.matthews@mh.org.au
}

Royal Melbourne Hospital Eating Disorders Unit, Melbourne, Australia

Submit your next manuscript to BioMed Central and take full advantage of:

- Convenient online submission

- Thorough peer review

- No space constraints or color figure charges

- Immediate publication on acceptance

- Inclusion in PubMed, CAS, Scopus and Google Scholar

- Research which is freely available for redistribution 